\title{
PROCESS TECHNOLOGY CONCERNING THE INTEGRATED SOLID INDUSTRIAL WASTE MANAGEMENT FOR THE PAPER INDUSTRY OPTIMIZED BY INFRARED APPROACH
}

by dr.eng. Elena Popa *, dr.eng. lonel Pisa*, dr.eng. Sorin Ignat **, eng. Cristina Ciobanu*, dr.eng. Manuela Georgescu*

\section{* Politehnica University of Bucharest, Romania \\ ** ENSAM Cluny, France}

\section{Abstract}

The paper present the work concerning technical possibilities to tamp the solid industrial waste coming out from an already refurbished paper plant in Adjud, Romania, in order to reduce the overall costs of the necessary landfill deposits and to create a real income by producing energy .

An infrared system of a FLIR S65 videocamera $(7-14 \mu \mathrm{m})$ and double wave length OMEGA OS3750 pyrometer $(0.9-1.5 \mu \mathrm{m})$ have been used in order to achieve the best thermal regime to ignite and to control the burning process of the industrial refuse.

\section{Introduction}

Most urban and industrial wastes include a significant quantity of humidity and ballast (mineral mass), meaning a reduced low heat value. The consequence is the flame temperature decrease and practically, deceleration of ignition and burning process. In order to diminish this inconvenient it is necessary to sustain the combustion process with a support fuel. The support fuel must be carefully selected, with high heat value and appropriate ratio. The choice of the support fuel must be done considering the quality of waste that must be incinerate, the economical and geographical availability.

The research presented in the paper refers to the possibility of removal by incineration of a solid industrial waste resulting from a paper plant in Romania. The incineration of this refuse is imposed by ecological demands and can be seen as a positive solution if the resulting energy is used. In this purpose, the energetic potential of the specific waste, it has been tested on two pilot boilers, one of $55 \mathrm{kWt}$, and the other of $2 \mathrm{MWt}$. Both pilot boilers are from the endowment of the Laboratory for combustion plants, from Politehnica University of Bucharest,.

The research has been focused on aspects concerning the ignition temperature, the necessary of support fuel, combustion efficiency and pollutant emissions.

The main purpose of this research is to create a thermal treatment for the primary solid waste, capable to be realized inside an industrial plant at a competitive cost, to produce energy at the same time of tamping the waste and not to produce pollutant emissions.

This paper presents the most important results of the entire research, pointing out especially aspects that have been elucidated by infrared approach.

\section{Physical properties of analyzed probes}

The research refers to a solid industrial refuse, sludge type, resulting from paper producing process. The refuse that is forward referred to as sludge is a soft deposit composed by fine particles, ashy (grey colored), with characteristic smell.

For the sludge resulted from the paper industry the first problem to solve is the drying process. In the dump heap (deposit) the sludge has an initial humidity of $90 \%$. By draining and pressing process, the humidity lowers at $38-40 \%$. This activity of preparing the waste, in order to incinerate it, is very important but expensive in the same time. Only after drying, the sludge can be energetic evaluated by combustion.

The main characteristics of the analyzed waste, after drying process, are presented below:

Table 1 Elemental analysis of sludge

\begin{tabular}{|l|c|c|}
\hline Parameter & U.M. & Probe \\
\hline Hygroscopic moisture & $\%$ & 38.80 \\
\hline Ash & $\%$ & 26.48 \\
\hline Sulph combustible & $\%$ & 0.10 \\
\hline Nitrogen & $\%$ & 0.25 \\
\hline Heat value & $\mathrm{kJ} / \mathrm{kg}$ & 5714 \\
\hline Inorganic Carbon & $\%$ & 14 \\
\hline
\end{tabular}




\section{Experiments on a small scale pilot boiler (55kWt)}

The purpose of the small scale tests is to study the ignition process in fuel bed. The thermal power of the chosen pilot boiler $(55 \mathrm{kWt}$ ) mark of the border between small boilers and high thermal power boilers (intended especially for rural heating or industrial needs for thermal energy consumers). For heating a residential or industrial space, for a radiation rate of $35-50 \mathrm{~W} / \mathrm{m} 3$, the $55 \mathrm{~kW}$ boiler can satisfy a volume in range of 1100 to $1500 \mathrm{~m} 3$. fuel bed.

Usually, the boilers with a thermal power up to $55 \mathrm{~kW}$ have fix grate and manual feed and rummage of the
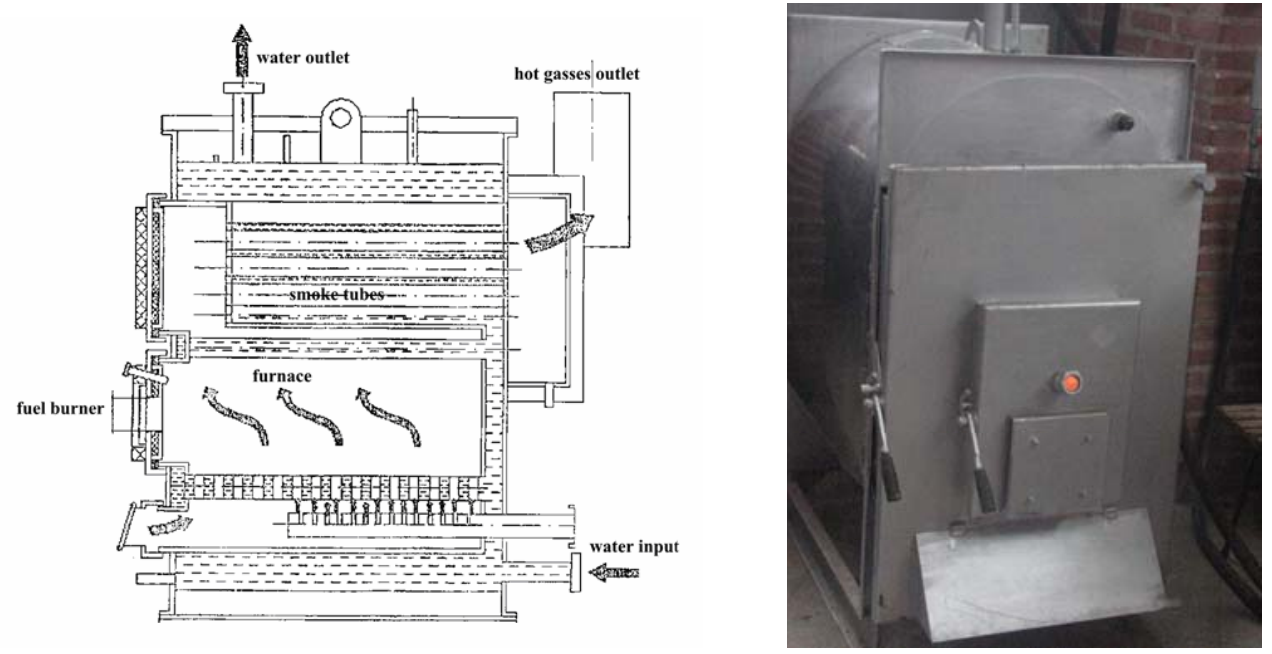

Fig. 1 The scheme of experimental pilot boiler of 55kWt

For reliable results the pilot boiler has been equipped with special measurement devices, such as:

- Flue gas analyzer MAXILYZER NG, a multifunctional device with built-in calculus functions. The analyzer can measure the hot gas and air temperatures, $\mathrm{CO}, \mathrm{O}_{2}, \mathrm{NO}, \mathrm{SO}_{2}$ emissions and furnace differential pressure; the analyzer can also calculate the $\mathrm{CO}_{2}$ emissions, the air excess coefficient and the boiler efficiency;

- A combustion control system, that allows the balance between the heat generated by fuel combustion, the heat accumulated by the flowing water and the heat losses;

- An infrared system of a FLIR S65 videocamera (7-14 $\mu \mathrm{m})$ and double wave length OMEGA OS3750 pyrometer $(0.9-1.5 \mu \mathrm{m})$

- A water flow meter made by Hokushin Electric Works (type F10A1152 A-ELT 310H), in range of $(0 \div 4000) \mathrm{kg} / \mathrm{h}$;

- Two $\mathrm{Hg}$ thermometers for cold and hot water, in range of $(0 \div 50)^{\circ} \mathrm{C}$, respectively $(0 \div 200)^{\circ} \mathrm{C}$;

The infrared system has been used in order to achieve the best thermal regime to ignite and to control the burning process of the industrial waste. Infrared process controlling tried to establish the optimum sludge mass flow rate towards the furnace in order to respect the necessary variations of temperature of the igniting layer to maintain a stabile flame.

Considering the reduced low heat value of sludge, the boiler starting up has been initiated with wood waste. Over the burning wood waste layer have been introduced the sludge from the left side of the grate (see fig. 2) in order to point out the temperature field both in support fuel layer and tested waste.

From infrared data acquired in sludge feeding stage (see fig. 2) the temperature of the support fuel layer is about $500-550^{\circ} \mathrm{C}$. Due to the sludge low heat value, the support fuel is important both for the sludge ignition and combustion. 


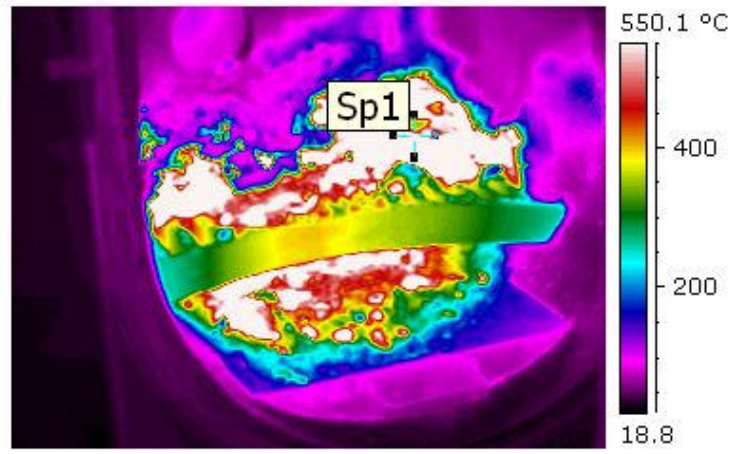

Fig. 2 Infrared image from sludge feeding stage defining the thermal field in support fuel layer

There has been noticed an almost constant level of temperature in range of $0-200^{\circ} \mathrm{C}$ in the sludge layer, as a result of its high humidity (much of the heat released by combustion is used to dry the sludge). The low level of temperature in sludge layer is also a consequence of volatile organic compounds reduced content resulting in an ignition delay. The only burning element from sludge is the coke base from carbon content.
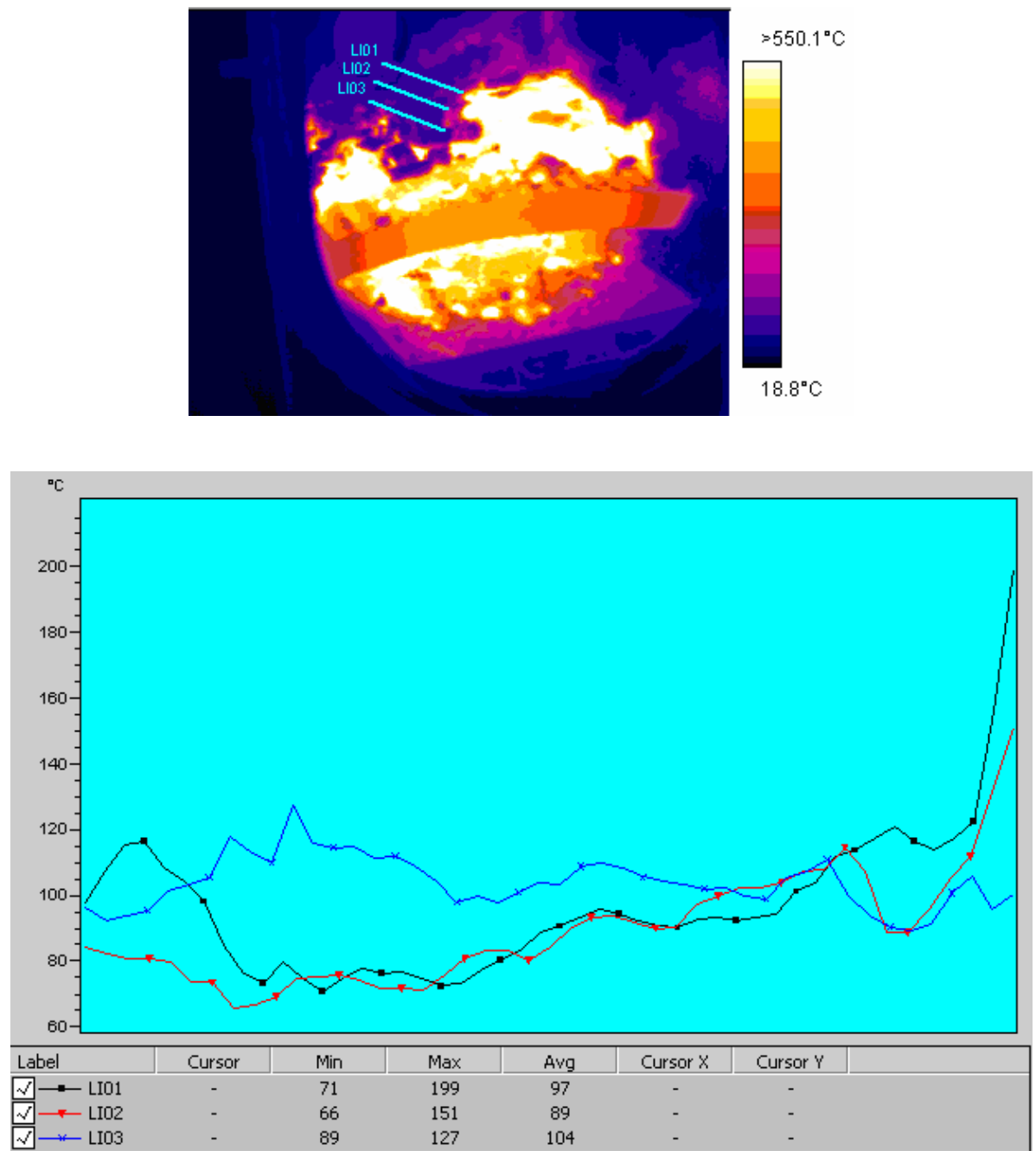

Fig. 3 Temperature fields in sludge layer 
Its important to mention a low level of pollutant emissions recorded by flue gases analyzer. This could be the positive aspect of the solution presented above.

The conclusion after the experiments on small scale are :

- the preparation time for ignition is long, characteristic for fuels with high moisture content;

- the waste ignition temperature is about $500-550^{\circ} \mathrm{C}$. This temperature must be realized within the furnace in starting stage with another fuel and maintained in normal sensitive time with thermal support fuel;

- from an energetic point of view, the sludge combustion requires an important amount of support fuel, the only benefit being its removal as waste;
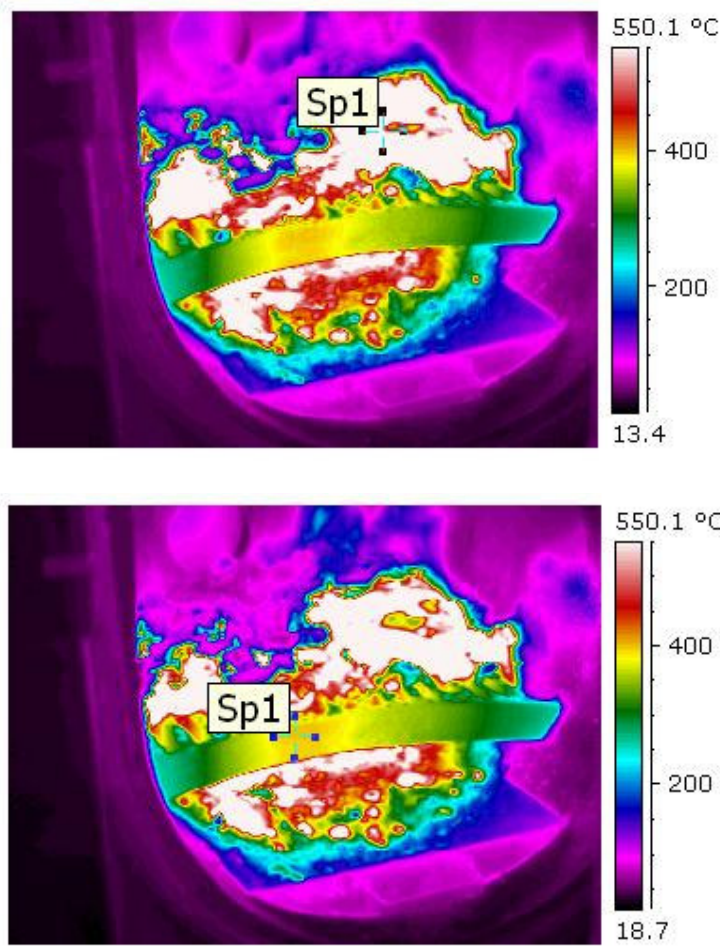

Fig. 4 Infrared images from waste combustion on grate from feeding stage and beginning of sludge volatilization.

\section{Experiments on pilot boiler of $2 \mathrm{MWt}$}

The tests continue to a bigger scale in order to see if the pollutants remain in the ash at the end of the process. In this purpose has been used as support fuel the natural gas (LHV $37500 \mathrm{~kJ} / \mathrm{m} 3 \mathrm{~N}$ ).

The experiments pursue to obtain certain details of in bed sludge incineration, flue gases composition, pollutant emissions and the combustion efficiency in order to optimize the combustion technology for this specific waste. It has been used the experience acquired by many studies and previous experiments with different types of biofuels and solid wastes.

The boiler has been equipped with a burning installation with an inclined grill at the base of the furnace. In order to sustain the sludge incineration, gas fuel burners has been placed over the grill.

The description of the experimental plant for solid fuel is presented below (see fig.5).

During the tests of sludge incineration, probes of cinder and ash have been sampled.

There are presented below the results of the laboratory analyses carried out for this samples (see table 2). In the same table there are also presented the pollutant emissions in flue gases resulted from the combustion process. 

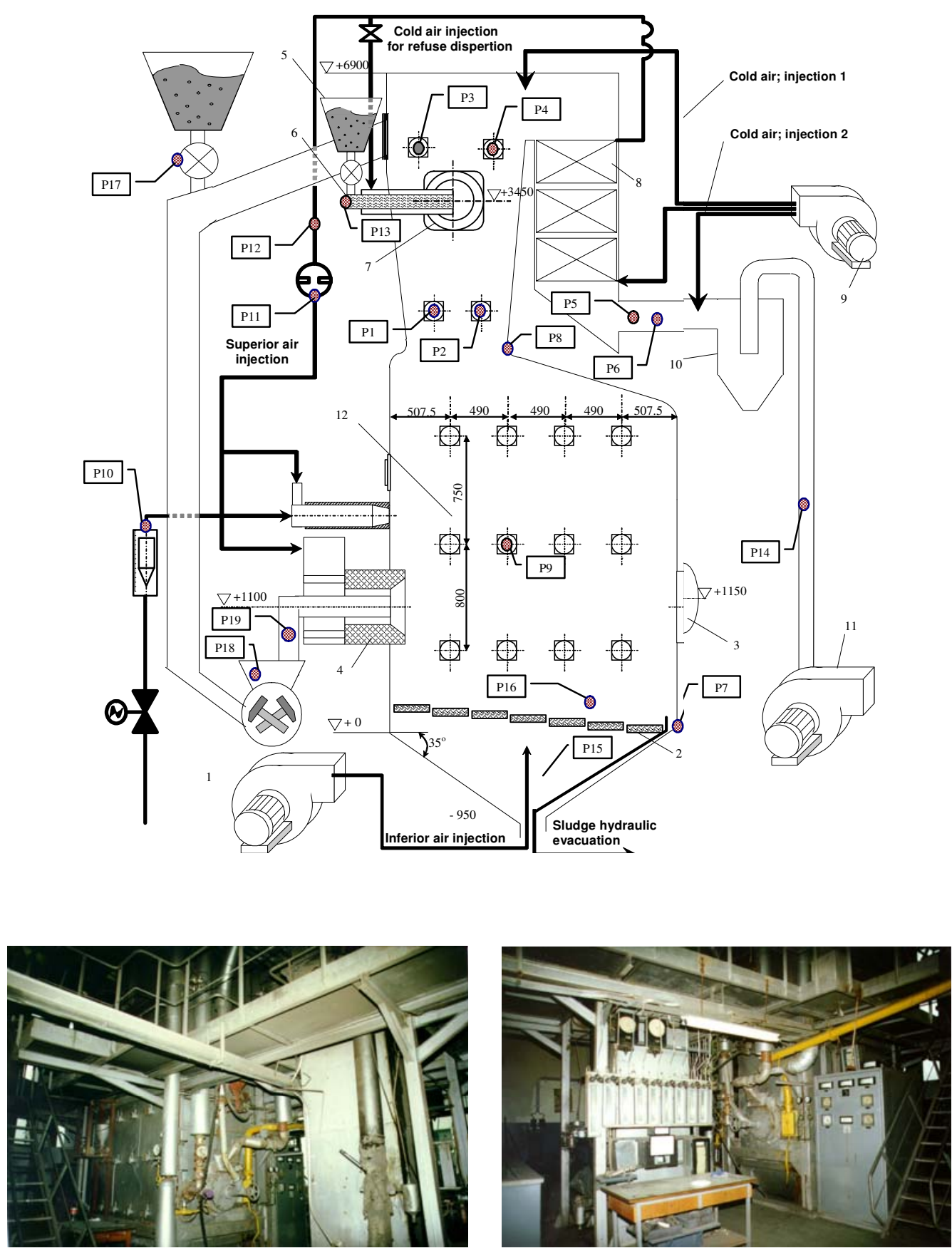

Fig.5 : Pilot installation of $2 M W t$ used to test the combustion process of paper refuse (1)Cold air ventilator ; 2)Post combustion grate ; 3) Visit hole; (4) Main burner; (5) secondary waste bunker; (6) Secondary feeding installation; (7)Secondary feeding orifice; (8) Tubular air preheater; (9) Main air ventilator; 10) Flying ash separator; (11) Flue gas ventilator; (12) Burning chamber;

$$
\text { (P10) - natural gas injection. }
$$


Table 2 Pollutants released in atmosphere from sludge burning process

\begin{tabular}{|c|c|c|c|}
\hline Pollutant & U.M. & $\begin{array}{c}\text { Probe } \\
\text { (measured } \\
\text { value) }\end{array}$ & $\begin{array}{c}\text { VLE-ORD. } \\
\text { MAPPM } \\
\text { nr.462/1993 } \\
\text { Pt<100 } \mathbf{~ M W t ~}\end{array}$ \\
\hline $\mathrm{NO}_{\mathrm{x}}\left(\mathrm{NO}_{2}\right)$ & $\mathrm{mg} / \mathrm{Nm}^{3}$ & $39 \div 63$ & 500 \\
\hline $\mathrm{CO}$ & $\mathrm{mg} / \mathrm{Nm}^{3}$ & $20 \div 64$ & 250 \\
\hline $\mathrm{SO}_{\mathrm{x}}\left(\mathrm{SO}_{2}\right)$ & $\mathrm{mg} / \mathrm{Nm}^{3}$ & 0 & 2000 \\
\hline $\mathrm{PCDD} / \mathrm{PCDF}$ & $\mathrm{mg} / \mathrm{Nm}^{3}$ & $\mathrm{SLD}$ & - \\
\hline $\mathrm{As}$ & $\mathrm{mg} / \mathrm{Nm}^{3}$ & 0.004 & 1 \\
\hline $\mathrm{Cd}$ & $\mathrm{mg} / \mathrm{Nm}^{3}$ & 0.0029 & 0.2 \\
\hline $\mathrm{Pb}$ & $\mathrm{mg} / \mathrm{Nm}^{3}$ & 0.013 & 5 \\
\hline $\mathrm{Ni}$ & $\mathrm{mg} / \mathrm{Nm}^{3}$ & 0.043 & 1 \\
\hline $\mathrm{Cr}$ & $\mathrm{mg} / \mathrm{Nm}^{3}$ & 0.059 & 5 \\
\hline $\mathrm{Mn}$ & $\mathrm{mg} / \mathrm{Nm}^{3}$ & 0.32 & 5 \\
\hline $\mathrm{Sb}$ & $\mathrm{mg} / \mathrm{Nm}^{3}$ & 0.00004 & 5 \\
\hline $\mathrm{Cu}$ & $\mathrm{mg} / \mathrm{Nm}^{3}$ & 0.040 & 5 \\
\hline $\mathrm{V}$ & $\mathrm{mg} / \mathrm{Nm}^{3}$ & 0.0087 & 5 \\
\hline $\mathrm{Co}$ & $\mathrm{mg} / \mathrm{Nm}^{3}$ & 0.0019 & 1 \\
\hline $\mathrm{Ti}$ & $\mathrm{mg} / \mathrm{Nm}^{3}$ & 0.000049 & 0.2 \\
\hline $\mathrm{Hg}$ & $\mathrm{mg} / \mathrm{Nm}^{3}$ & 0.0000086 & 0.2 \\
\hline
\end{tabular}

Major conclusions from this part of research are the following:

- natural tamping mass ratio (between the primary waste and the final ash) has been obtained at an average value of 4.75 ;

- thermal regime has generated no dioxins and no furan in the flue gas;

- no heavy metal mass fraction has been detected in the ash;

- carbon monoxide emissions (by NDIR methods) have been lower than $260 \mathrm{mg} / \mathrm{Nm}_{3}$ at $6 \%$ oxygen content in the flue gas;

- NOx emissions (by chemiluminescence's) have been lower than $65 \mathrm{mg} / \mathrm{Nm}_{3}$ at $6 \%$ oxygen content in the flue gas;

- the unburned material found in the ash did not exceed $4.3 \%$;

This work has been carried out by a scientific team from Politehnica University of Bucharest, ICPET-ECO SA Bucharest (all Romanian institutions) under a private financed research project by VRANCART SA Plant from Adjud, Romania (quoted at the Bucharest Stock Exchange, Romania).

The research project has been finished at the middle of July 2007. The obtained results are to be implemented at the VRANCART SA paper plant nearby Adjud (Vrancea district). Special acknowledgements have also to be presented to the Scientific Research Center for Defense N.B.C. and Ecology - Bucharest and PROSPECTIONS SA Bucharest, for homologations and official analysis concerning heavy metals in the resulted ash and dioxins and furan content of the flue gas.

\section{REFERENCES (selective)}

[1] L. Mihăescu, T. Prisecaru, M. E. Georgescu, I. Pîşă "Pollution limits for combustion of paper industry waste, ETCNUR 2007, 5-6 july, 2007, Bucharest, Romania

[2] M. Georgescu, V. Matcaşu, The energetic revaluation, by burning, of the combustible sludge resulted from the paper producing industry, $3^{\text {rd }}$ International Conference on Energy and Environment CIEM2007, Bucharest, 22-23 November, Bucharest, Romania

[3] A. Mihai, Infrared Thermography, Ed. Tehnica, Bucharest 2005, $360 \mathrm{pp}$ 